Reprod. Nutr. Dévelop., 1983, 23 (2 B), 389-401.

\title{
Insulin binding to skeletal muscle membranes in growing ruminating sheep fed different diets
}

\author{
J. GRIZARD \\ With the technical assistance of Marie-Louise HOULIER, Claire SORNET, A. SELLE and M. SALLAS \\ Laboratoire d'Etude du Métabolisme azoté, I.N.R.A., \\ Theix, Saint-Genès-Champanelle, 63110 Beaumont, France.
}

Summary. The purpose of this work was to investigate insulin receptors in skeletal muscle of growing $(30-36 \mathrm{~kg})$ ruminating sheep given a control diet or undergoing nitrogen restriction. The membranes were purified according to Kidwaï from sternocephalicus muscle which has a low glycolytic and a moderate oxidative capacity. This preparation concentrated $5^{\prime}$-nucleotidase activity, indicating that it contained plasma membrane and transverse tubules. The high levels of cytochrome-c oxidase activity suggested mitochondrial contamination. Such a preparation is also known to contain sarcoplasmic reticulum.

${ }^{125} \mathrm{I}$-insulin binding to purified membranes was studied at 4 and $30^{\circ} \mathrm{C}$ at various times, insulin concentrations and membrane levels. Total ${ }^{125}$-insulin binding increased with time, reaching a maximal value within $16-24 \mathrm{~h}$ at $4^{\circ} \mathrm{C}$ or within $1-2 \mathrm{~h}$ at $30^{\circ} \mathrm{C}$. When measured at steady state at $30^{\circ} \mathrm{C}$, specific ${ }^{125} \mathrm{I}$-insulin binding was found to be a linear function of membrane concentration. At low insulin levels, specific ${ }^{125} \mathrm{I}$-insulin binding was not significantly different at 4 and $30^{\circ} \mathrm{C}$. Increasing the unlabelled insulin level inhibited ${ }^{125}$-insulin binding. At steady state, specific ${ }^{125}$-insulin binding accounted for about $40 \%$ of the total binding.

The protein yield in the membrane preparation was similar in both groups. $5^{\prime}$-Nucleotidase, a plasmolemma-bound enzyme, was lower in experimental group membranes than in control group ones. In contrast, cytochrome-c oxidase increased. These findings were in keeping with a decrease in membrane purity in the experimental group. We therefore expressed insulin binding in terms of $5^{\prime}$-nucleotidase activity. At both temperatures and over a wide range of insulin concentrations, including saturating concentrations, specific ${ }^{125} \mathrm{I}$-insulin binding at steady state was 2 to 5 -fold higher in the experimental than in the control group. Insulin breakdown in the incubation tube was negligeable in both groups.

\section{Introduction.}

Muscle is no doubt the major target tissue of insulin, a hormone that stimulates glucose and amino acid transport. Insulin promotes protein synthesis but impairs protein breakdown; it also increases glycolysis and glycogen synthesis (Turner and Muriday, 1976 . Goldberg, 1979 ; Jefferson, 1980 ; Tischler, 1981 ; Etherton, 1982). However, protein metabolism in muscles such as the 
soleus, that contains predominately slow-twitch red fibers, is relatively insensitive to the effects of diabetes and insulin (Preedy, Pain and Garlick, 1980 ; Flaim, Copenhaver and Jefferson, 1980).

Insulin binding to cell surface receptors is known to be the initial step in insulin action and to control it (Freychet, 1976 a ; Goldfine, 1978 ; Olefsky, 1981). Unsuccessful attempts have been made to quantify insulin binding to muscle (Newerly and Berson, 1957; Wohltmann and Narahara, 1966). Subsequent studies ascertained the presence of insulin receptors in membranes of skeletal and cardiac muscle (Forgue and Freychet, 1975; Olefsky, Bacon and Baur, 1976; Saucier, Dubé and Tremblay, 1981), isolated soleus muscle (Le Marchand-Brustel, Jeanrenaud and Freychet, 1978 ; Hofmann and Nakano, 1981 ; Brady et al., 1981) and isolated muscle cells (Sandra and Przybylski, 1979; Eckel and Reinauer, 1980).

In ruminants, little glucose is directly derived from dietary carbohydrate since it is converted to volatile fatty acids as a result of microbial fermentation in the rumen. The major site of glucose supply is the liver. This correlates with the fact that glucose is not the major metabolic substrate in peripheral ruminant tissues. Insulin regulation of metabolism has been poorly understood because the drop in blood glucose following exogenous insulin is generally thought to be less than in non-ruminant species; furthermore, the fall in blood free amino acids is unclear (Bassett, 1975 ; Trenkle, 1978). However, ruminant tissues do contain insulin receptors (Grizard and Szczygiel, 1983 ; Vernon, Clegg and Flint, 1980 ; Gill and Hart, 1981 ; Kappy et al., 1981 ; Sinha, Ganguli and Sperling, 1981) and are responsive to insulin (Scharrer, Hüntemann and Blatt, 1977 ; Vivekanandan and Singh, 1978).

Bearing this in mind, we decided to investigate the insulin receptors in skeletal muscle membranes of growing ruminant sheep fed a control diet or an experimental diet low in crude protein and high in propionic acid used as a feed additive. Nitrogen restriction is indeed important in animal production.

\section{Material and methods.}

Animals and experimental procedure. - We used the male progeny of Romanov $\times$ Limousin sheep born the second week of November and weighing an average of $18 \mathrm{~kg}$. They were housed in individual stalls under naturat lighting conditions in a room maintained at $20-22{ }^{\circ} \mathrm{C}$. The animals were divided into two groups, one given a control diet and the other an experimental diet. The control diet was similar to the usual diets for growing sheep (table 1). The experimental diet was also within the range or normal sheep nutrition. The diets had two major differences. First, the experimental diet did not contain high-protein ingredients, such as soya-bean meal and linseed oil meal, and therefore included less crude protein $(N \times 6.25)$ than the control diet $(12.6$ vs 14,7\%). Second, there was more propionic acid in the experimental than in the control diet and it was used as a feed additive in maize. The animals were given a complete ration at 08.30. Water was provided ad libitum. 
TABLE 1

Composition of the diets

(percent of dry matter)

\begin{tabular}{|c|c|c|}
\hline Ingredients & Control diet ${ }^{\mathrm{a}}$ & Experimental diet \\
\hline Dehydrated alfalfa & 26.1 & 29.1 \\
\hline Urea ........... & 0.4 & 0 \\
\hline Soy-bean meal (50\% crude protein) & 3.4 & 0 \\
\hline Linseed oil meal ................. & 1.4 & 0 \\
\hline Maïze : & & \\
\hline - with propionic acid supplement.. & 37.2 & 67.5 \\
\hline - without propionic acid suppiement & 27.2 & 0 \\
\hline Propionic acid .................. & 0.6 & 1.2 \\
\hline Molasses .... & 0.4 & 0 \\
\hline Vitamin-minerals & 3.3 & 2.2 \\
\hline
\end{tabular}

a In the control diet, urea, soy-bean meal, linseed oil meal and molasses were supplied by a standard concentrate. This also included maïze, which was not supplemented with propionic acid, and $40 \%$ of vitamin-minerals.

Due to a small decrease in the voluntary intake of ingredients such as dehydrated alfalfa and maize (supplemented with propionic acid), the true nutritional status of the animals was slightly different from the expected status. For example, nitrogen intake in the control group was slightly lower than the estimated nitrogen requirements for $20-27 \mathrm{~kg}$ body weight (BW) (table 2), whereas it was adequate for $27-34 \mathrm{~kg} \mathrm{BW}$. However, at any BW, gain and feed efficiency were acceptable in the control animals. Daily protein intake was significantly lower in the experimental than in the control group $(-35 \%$ and $-23 \%$ at 23 and $33 \mathrm{~kg}$ of live weight, respectively). In addition, at $20-27 \mathrm{~kg}$ of live weight, daily intake of dry matter was reduced $(-21 \%)$ in the experimental group. At $20-27 \mathrm{~kg}$ of live weight, that group grew significantly slower ( - $24 \%$ ) but at $27-34 \mathrm{~kg}$ of live weight, growth was similar in both groups. When the animals had a mean BW of $34 \mathrm{~kg}$ (i.e. at 15.5 weeks of age in the control group and 18.0 weeks in the experimental), they were slaughtered without anesthesia between p.m. 03.00 and p.m. 04.00. To study skeletal muscle receptors, the two sternocephalicus muscles were quickly removed and freeze-dried in liquid nitrogen at $-80^{\circ} \mathrm{C}$ until use. On the basis of its enzymatic activity, the

TABLE 2

Animal characteristics ( $₹ \mathrm{SE}$ )

\begin{tabular}{|c|c|c|c|c|}
\hline \multirow{2}{*}{$\begin{array}{l}\text { Liveweight } \\
\text { Group }\end{array}$} & \multicolumn{2}{|c|}{$20-27 \mathrm{~kg}$} & \multicolumn{2}{|c|}{$27-34 \mathrm{~kg}$} \\
\hline & Control & Experimental & Control & Experimental \\
\hline \multirow{4}{*}{$\begin{array}{l}\text { Daily intake }(g) \\
\text { dry matter ............ } \\
\text { digestible crude protein .. }\end{array}$} & & & & \\
\hline & $928 \mp 30$ & $733 \mp 71$ & $1079 \mp 42$ & $1020 \mp 27$ \\
\hline & $90 \mp 3$ & $58 \mp 6$ & $105 \mp 5$ & $81 \mp 2$ \\
\hline & $272 \mp 12$ & $207 \mp 14$ & $281 \mp 34$ & $303 \mp 34$ \\
\hline
\end{tabular}


sternocephalicus muscle exhibited a low glycolytic and a moderate oxidative capacity. Therefore, it was considered to be a slow-twitch muscle containing mixed red and white fibers $\left({ }^{*}\right)$.

Chemicals. - Purified monocomponent porcine insulin (MC S 8301765 , $26.0 \mathrm{IU} / \mathrm{mg}$ ) was obtained from the Novo Research Institute, Bagsvaerd, Denmark. ${ }^{125} \mathrm{I}-\mathrm{Na}$ (IMS. 30) was purchased from the Radiochemical Center, Amersham, England. 5' -AMP was purchased from Merck, and bovine serum albumin (fraction V), thymidine $5^{\prime}$-monophospho-P-nitrophenyl ester, p-nitrophenol and cytochrome-c from Sigma Chemical Co.

125/-monoiodoinsulin was prepared according to the method of Freychet (1974) and purified by chromatography on a DEAE cellulose column. This preparation contained about $55 \%$ 1251-monoiodoinsulin and $45 \%$ unlabelled insulin since average specific activity, measured by the trichloracetic acid method, was nearly $200 \mu \mathrm{Ci} / \mu \mathrm{g}$. Monoiodoinsulin had been shown previously to be biologically active and its interaction with the receptor could not be distinguished from that of native insulin (Freychet, Roth and Neville, 1971).

Muscle membranes. - Purified membranes were prepared as described by Kidwaï et al. (1971) and Forgue and Freychet (1975) with the following modifications. The random samples $(3.5-5.0 \mathrm{~g})$ of frozen muscle taken from one animal were minced with scissors and thawed within $2-5 \mathrm{~min}$ in $8 \%$ (W/W) sucrose at $4{ }^{\circ} \mathrm{C}$. They were homogenized in the same medium with a polytron PT 20 set at half-maximum speed for $25 \mathrm{sec}$. The homogenate was filtered through six different mesh sizes $(16,20,30,40,60,80)$ of nytrel cloth (Desjobert, Paris, France) using a filtration device. The filtrate was centrifuged at $75000 \times \mathrm{g}$ max for $75 \mathrm{~min}$. The resulting pellet was resuspended in a small volume of $8 \%(W / W)$ sucrose and loaded on the top of a sucrose gradient (28$56 \%, \mathrm{~W} / \mathrm{W}$ ) that was centrifuged at $90000 \times \mathrm{g}$ max for $120 \mathrm{~min}$. The two top bands in the gradient were collected, diluted with water to reduce the concentration of sucrose to $8 \%(\mathrm{~W} / \mathrm{W})$ and then centrifuged at $90000 \times \mathrm{g}$ max for $60 \mathrm{~min}$. This final pellet was washed in $1 \mathrm{mM} \mathrm{NaHCO}$, centrifuged at $25000 \times \mathrm{g} \max$ for $15 \mathrm{~min}$, and stored at $-80^{\circ} \mathrm{C}$ until used. Protein concentrations were determined (Lowry et al., 1951) using bovine albumin as a standard. 5'Nucleotidase activity, a standard marker for plasma membrane, was determined by measuring the rate of inorganic phosphate release from $5^{\prime}$ AMP (Aronson and Touster, 1974). Both soluble phosphodiesterase activity and the activity of that in membrane particles were determined by measuring the release rate of $p$-nitrophenol from thymidine $5^{\prime}$-monophospho-p-nitrophenyl ester (Aronson and Touster, 1974). Cytochrome oxidase, a standard mitochondrial inner membrane marker, was evaluated by measuring the rate of enzymatic oxidation of reduced cytochrome c (Cooperstein and Lazarow, 1951). Quick freezing and quick thawing induced some variations in the muscle fractions.

$\left({ }^{*}\right)$ We wish to thank A. Talmant and G. Monin for determining the fiber type of the sternocephalicus muscle. 
Indeed, in growing rats we found that $5^{\prime}$-nucleotidase, phosphodiesterase and cytochrome oxidase activities per $\mathrm{mg}$ of membrane protein were significantly higher $(p \leqslant 0.05)$ in membranes from freeze-thawed skeletal muscle samples than in membranes of corresponding fresh muscle samples. However, specific insulin binding was not significantly reduced, whether expressed in terms of membrane protein or $5^{\prime}$-nucleotidase activity (Grizard, unpublished results).

Binding studies. - ${ }^{125} \mathrm{~J}$-insulin binding was studied according to the procedure of Freychet (1976 b) with some minor modifications. Incubation was performed at $2-4{ }^{\circ} \mathrm{C}$ and $30^{\circ} \mathrm{C}$ in Krebs Ringer phosphate buffer $140 \mathrm{mM} \mathrm{NaCl}$, $1.7 \mathrm{mM} \mathrm{KCl}, 0.4 \mathrm{mM} \mathrm{Mg} \mathrm{SO}, 0.4 \mathrm{mM} \mathrm{KH}_{2} \mathrm{PO}_{4}, \mathrm{pH}$ 7.5) with membrane protein at $0.05-0.24 \mathrm{mg} / \mathrm{ml}$ and bovine serum albumin at $10 \mathrm{mg} / \mathrm{ml}$ in a final volume of $0.25 \mathrm{ml}$ per incubation tube. The incubation mixture also contained ${ }^{125} \mathrm{l}$-insulin at $0.02 \mathrm{nM}$ or $0.1 \mathrm{nM}$ and unlabelled insulin at various concentrations from 0 to $350 \mathrm{nM}$. Incubation was terminated at the times shown in the figure legends by cooling the incubation tubes in an ice bath. To study the time-course of binding at $30^{\circ} \mathrm{C}$, the total membrane-bound radioactivity in each incubation tube was isolated by filtration on cellulose acetate membrane filters $10.45 \mu \mathrm{m}$, Nuflow, Oxoid). In all the other studies, a 150- $\mu$ l aliquot from each incubation tube was transferred into the top of a microfuge tube filled with $200 \mu \mathrm{l}$ of chilled buffer. The microfuge tube was then centrifuged for $10 \mathrm{~min}$ at $25000 \times \mathrm{g}$ at $4{ }^{\circ} \mathrm{C}$. The supernatant was sucked out and the tip of the tube was cut above the membrane pellet. Radioactivity in the tube tip and the filters was counted. Total binding referred to membrane-bound radioactivity, whereas non-specific binding represented membrane-bound radioactivity in the presence of a large excess $(11 \mu \mathrm{M})$ of unlabelled insulin. Specific binding was the difference between total and non-specific binding.

Intact insulin in the incubation medium. - In the studies of insulin binding at steady state, ${ }^{125}$-labelled insulin, intact in the supernatants from the incubation mixtures (insulin at $0.02,0.2$ and $0.9 \mathrm{nM}$ and membrane $5^{\prime}$ nucleotidase at $0.3 \mu$ moles of inorganic phosphate $/ \mathrm{h} / \mathrm{ml}$, i.e. membrane protein at $0.15 \mathrm{mg} / \mathrm{ml}$ ), was evaluated by measuring the ability of insulin to rebind to liver membranes of growing rats (membrane protein : $0.17-0.25 \mathrm{mg} / \mathrm{ml}$ ) (Freychet et al., 1972). These membranes were prepared according to the procedure of Neville (1968). The percentage of intact insulin (mean of 3 insulin concentrations) was similar in both groups $\left(93 \pm 10\right.$ and $141 \pm 26$ at 4 and $30^{\circ} \mathrm{C}$, respectively: $\pm \mathrm{SE}: 6$ animals in each group, 3 assays per animal).

Statistical analysis. - The groups were compared by variance analysis. Linear unweighted regressions were used (Snedecor and Cochran, 1971).

\section{Results.}

Characteristics of the plasma membrane preparation. - The membrane preparation isolated by the procedure of Kidwaï contained the plasmolemma since it concentrated 5'-nucleotidase activity la plasma membrane enzyme 
marker). It has been established that this preparation also contains sarcoplasmic reticulum. As indicated by cytochrome-c oxidase activity (table 3), the preparation also had some mitochondrial components. Cardiac mitochondrial membranes specifically bind insulin, but 5 to 14 times less than plasma membranes (Forgue and Freychet, 1975).

The protein yield of $1 \mathrm{~g}$ of fresh muscle was similar in both groups (table 3 ). Protein recovery ranged between 1.5-1.6\%. 5' -Nucleotidase, expressed in terms of protein, was significantly lower $(0.050<p<0.100)$ in the experimental than in the control group.

Binding time-course. - At $4{ }^{\circ} \mathrm{C}$, total ${ }^{125}$-insulin binding increased slowly during the 16-hour period after incubation began (fig. 1); it then increased no

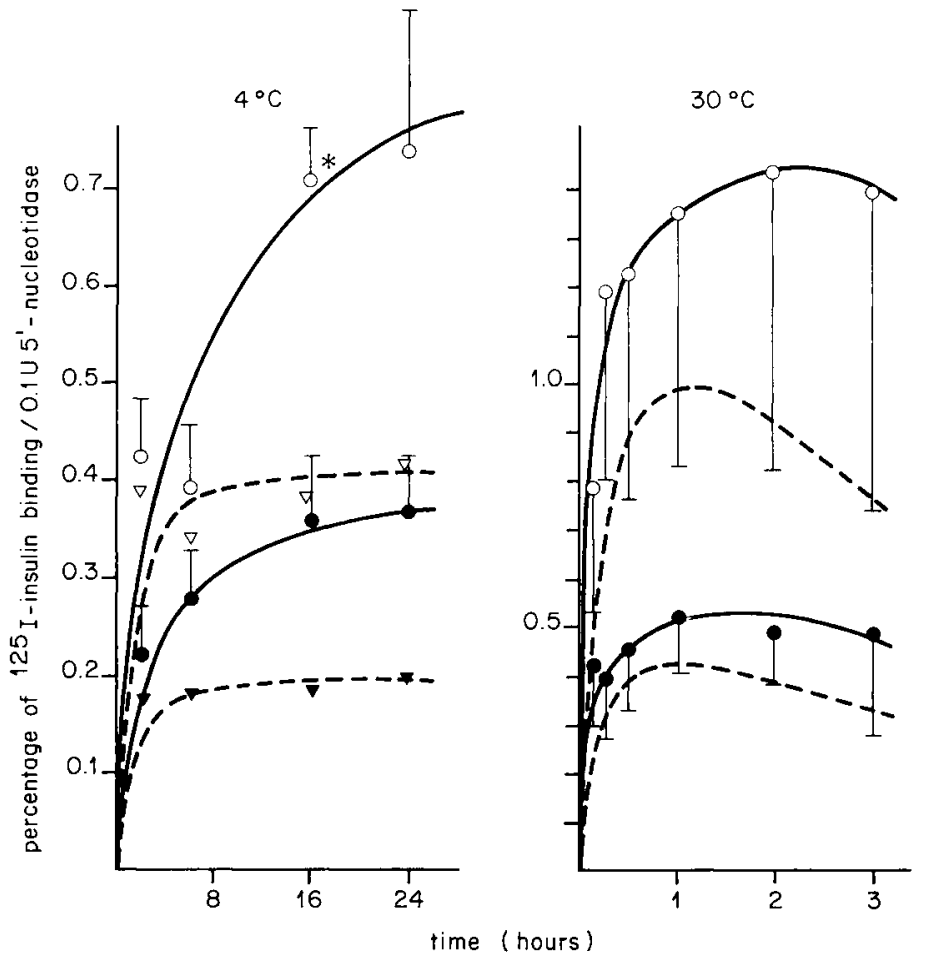

FIG. 1. - Time-course of 125 -insulin binding at $4{ }^{\circ} \mathrm{C}$ (left plot) and $30{ }^{\circ} \mathrm{C}$ (right plot). - - : total insulin binding in the control group; - - : total insulin binding in the experimental group; -- - -. : non-specific insulin binding in the control group at $4{ }^{\circ} \mathrm{C} ;-\nabla-{ }_{-}$: non specific insulin binding in the experimental group at $4^{\circ} \mathrm{C}$. Each point is the mean $\mp$ SE for six and five individual values (at $4{ }^{\circ} \mathrm{C}$ ) or five and six individual values (at $30^{\circ} \mathrm{C}$ ) in the control group and the experimental group, respectively. Each value is the mean of duplicate determinations for one experiment. (----) : non-specific insulin binding at $30^{\circ} \mathrm{C}$; due to the lack of some determinations, this one was calculated by curvilinear regression. * : significantly different $(0.050<P<0.100)$ from controls. ${ }^{125}$-insulin 10.024 and $0.095 \mathrm{nM}$ at 4 and $30{ }^{\circ} \mathrm{C}$, respectively) was allowed to bind to the membranes $\left(5^{\prime}\right.$-nucleotidase at 0.34 and $0.44 \mu$ moles of inorganic phosphate/hour $/ \mathrm{ml}$ at 4 and $30{ }^{\circ} \mathrm{C}$, respectively, i.e. membrane protein at 0.17 and $0.23 \mathrm{mg} / \mathrm{mll}$. At the times indicated, membrane-bound radioactivity was isolated by centrifugation (at $4^{\circ} \mathrm{C}$ ) and filtration (at $30^{\circ} \mathrm{C}$ ). Results are expressed as the percent of ${ }^{125} \mathrm{I}$-insulin bound per $0.1 \cup 5^{\prime}$-nucleotidase (i.e. $0.1 \mu$ moles of inorganic phosphate $/$ hour $/ \mathrm{ml}$ ). 
TABLE 3

Protein and enzymatic activities in the membrane preparation

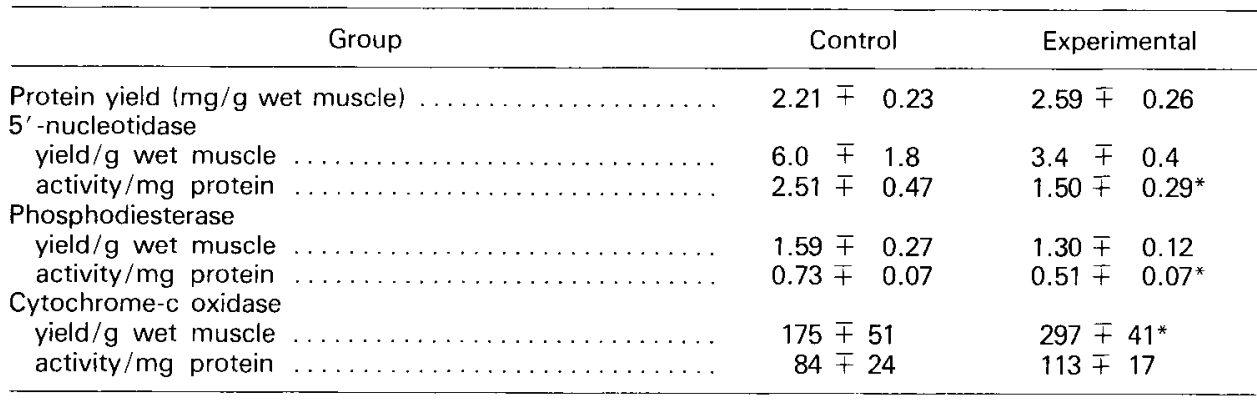

$5^{\prime}$-Nucleotidase is expressed in $\mu$ moles of inorganic-phosphate/mg protein/hour, phosphodiesterase is expressed in $\mu$ moles of $\mathrm{p}$-nitrophenol $/ \mathrm{mg}$ protein/hour, and cytochrome-c-oxidase is expressed in nanomoles of cytochrome-c oxidized $/ \mathrm{min}$. Each value is the mean $\mp$ SE of six values in each group. ${ }^{*}$ : significantly different $(0.050<\mathrm{P}<0.100)$ from controls.

more. At $16 \mathrm{~h}$, it was significantly higher $(0.050<p<0.100)$ in the experimental than in the control group. Non-specific insulin binding was constant at all the investigated times. In each group, it was similar to steady-state specific insulin binding. In contrast, at $30^{\circ} \mathrm{C}$ total insulin binding attained steady state

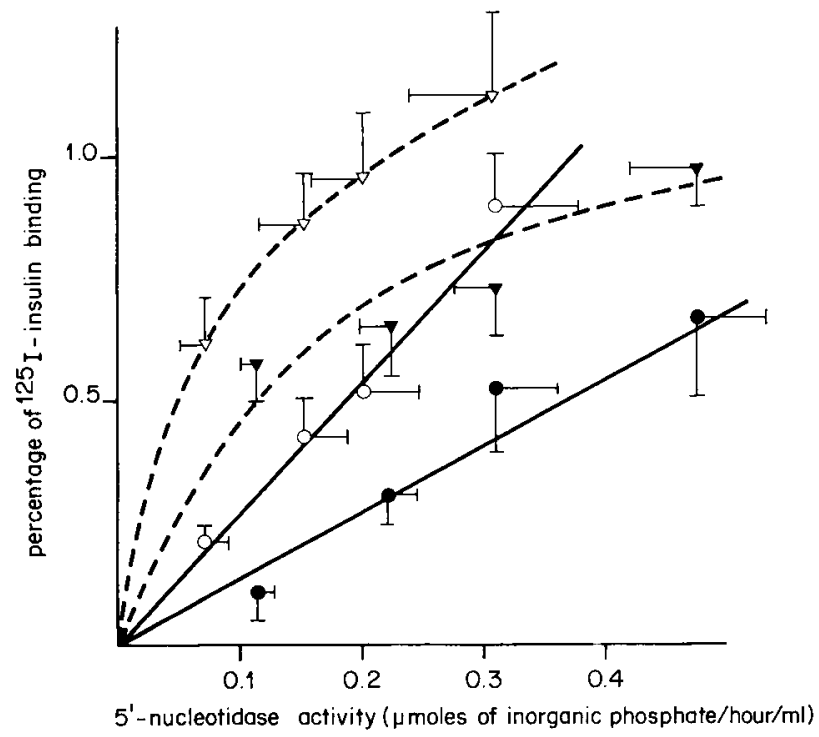

FIG. 2. - Steady-state $125 /$-insulin binding at various levels of muscle membrane at $30^{\circ} \mathrm{C}$. - - : specific insulin binding in the control group; $-0-$ : specific insulin binding in the experimental group; -- $\mathbf{\nabla} \cdot-$ : non-specific insulin binding in the control group ; -- $\nabla--:$ nonspecific insulin binding in the experimental group. Each point is the mean $\bar{F}$ SE of six individual values in each group. Each value represents the mean of duplicate determinations for one experiment. ${ }^{125} /$-insulin $(0.018 \mathrm{nM})$ was allowed to bind to the membranes $\left\{5^{\prime}\right.$-nucleotidase within 0.08-0.5 $\mu$ moles of inorganic phosphate/hour $/ \mathrm{ml}$, i.e. membrane protein at $0.06,0.11,0.16$ and $0.21 \mathrm{mg} / \mathrm{ml}$ ) for 1 hour at $30^{\circ} \mathrm{C}$. Membrane-bound radioactivity was isolated by centrifugation. 
$1 \mathrm{~h}$ after incubation began. The results showed large individual variations in the experimental group.

Insulin binding at steady state. - Specific ${ }^{125}$-insulin binding increased linearly with increased membrane levels over a 6 -fold range at $30^{\circ} \mathrm{C}$ (fig. 2). The rate of increase was significantly higher $(0.050<p<0.100)$ in the experimental than in the control group $(2.8 \% \mu$ mole of inorganic phosphate $/ \mathrm{h} / \mathrm{ml} v s$ 1.5).

At low insulin levels, specific ${ }^{125}$-insulin binding was not significantly different in either group at 4 and $30^{\circ} \mathrm{C}$ (fig. 3). At both temperatures, it decreased with increased insulin concentration. At physiological insulin levels (0.3-0.8 nM), ${ }^{125}$ - -insulin binding was not decreased significantly. With $0.02,3.6$, 82 and $348 \mathrm{nM}$ insulin at $4{ }^{\circ} \mathrm{C}$ and with $0.02,0.9$ and $82 \mathrm{nM}$ insulin at $30^{\circ} \mathrm{C}$, specific 125 -insulin binding seemed higher $(0.010<p<0.100)$ in the experimental than in the control group. At both temperatures, the non-specific 125/-insulin binding in each group was similar to maximal specific ${ }^{125}$-insulin binding.

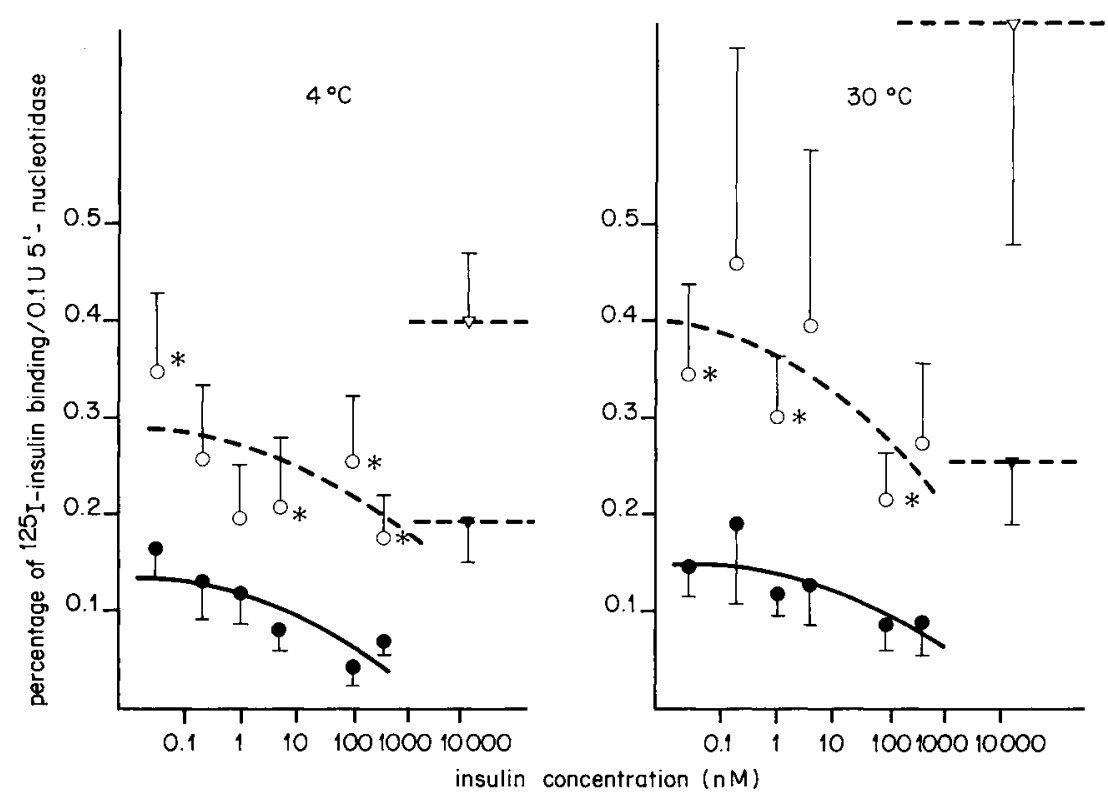

FIG. 3. - Steady-state 125 -insulin binding at various levels of insulin concentration at $4{ }^{\circ} \mathrm{C}$ (left plot) and $30^{\circ} \mathrm{C}$ (right plot). - - : specific insulin binding in the control group ; - - : specific insulin binding in the experimental group ; -- $\mathbf{\nabla - -}$ : non-specific insulin binding in the control group ; $-\nabla-$ : non-specific insulin binding in the experimental group ${ }^{*}:$ significantly different $(0,010<P<0,100)$ from controls. Each point is the mean SE for six and four individual values in the control group and the experimental group $\left(a t{ }^{\circ} \mathrm{C}\right.$ ) or for six individual values in each group (at $30^{\circ} \mathrm{C}$ ). Each value represents the mean of duplicate determinations for one experiment. ${ }^{2} 5$-insulin $(0.021 \mathrm{nM})$ was allowed to bind to the membranes $\left(5^{\prime}\right.$-nucleotidase at $0.30 \mu$ moles of inorganic phosphate $/$ hour $/ \mathrm{ml}$, i.e. membrane protein at $0.15 \mathrm{mg} / \mathrm{ml} /$ for 1 hour. Membrane-bound radioactivity was isolated by centrifugation. Results are expressed as the percent of 125 -insulin bound per $0.1 \cup 5^{\prime}$-nucleotidase (i.e. $0.1 \mu$ mole of inorganic phosphate/hour/mi). 
The amount of specifically bound insulin rose with increasing free insulin (fig. 4) ; maximal binding was not attained with $350 \mathrm{nM}$ insulin. At both temperatures and over a wide range of insulin concentrations, including saturating concentrations, the amount of specifically bound insulin was 2 to 5fold higher in the experimental than in the control group. This suggests that an increase in binding sites mainly accounted for the increment in insulin binding to membranes of the experimental group. Due to wide individual variations, Scatchard analysis was not accurate enough to give the affinity constant and binding capacities for each group. However, it gave a curvilinear plot (not shown) consistent with either of two types of independent site, negative cooperativity in binding, or both (Kahn et al., 1974, 1978).

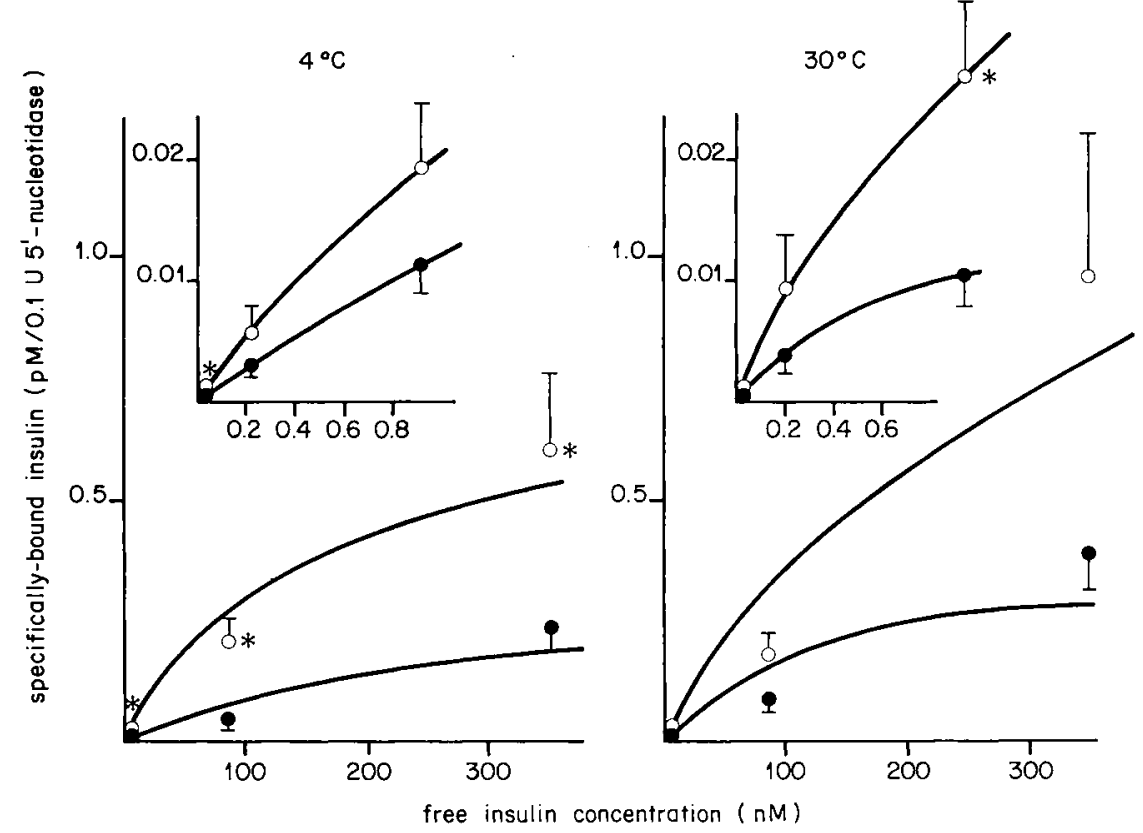

FIG. 4. - Insulin specifically bound as a function of free insulin concentration at $4{ }^{\circ} \mathrm{C}$ (left plot) and $30{ }^{\circ} \mathrm{C}$ (right plot). - - : control group ; - $\mathrm{O}-$ : experimental group ; ${ }^{*}$ : significantly different $(0.010<P<0.100)$ from controls. The data were calculated from results shown in figure 3. Bound insulin $=$ (percent of 125 -insulin specifically bound) $\times$ (total insulin concentration). Free insulin $=$ (total insulin) - (specifically bound insulin + non-specifically bound insulin). The data for low insulin levels are shown in the insets.

\section{Discussion.}

This study demonstrates that skeletal muscle from growing ruminant sheep contains specific insulin receptors. As opposed to data on erythrocyte receptors (Kappy et al., 1981; Sinha, Ganguli and Sperling, 1981), muscle insulin receptors did not disappear in the transition from a monogastric to a ruminant metabolic state. This correlates with the presence of insulin receptors in liver (Gill 
and Hart, 1980, 1981), adipose tissue (Vernon, Clegg 'and Flint, 1980) and other various tissues (Posner et al., 1974) of adult ruminant animals. Muscle insulin receptors of ruminant sheep are very similar to muscle insulin receptors in rodents (Forgue and Freychet, 1975; Olefsky, Bacon and Baur, 1976 ; Le Marchand-Brustel, Jeanrenaud and Freychet, 1978 ; Eckel and Reinauer, 1980 ; Hoffmann and Nakano, 1981 ; Brady et al., 1981). These similarities include time and membrane level dependence of binding and apparent kinetic parameters. The presence of insulin receptors is correlated with the ability of insulin to elicit a biological response in ruminant muscles (Scharrer, Hüntemann and Blatt, 1977 ; Vivekanandan and Singh, 1978).

Feeding the experimental diet increased specific insulin binding to muscle membranes. This result could not be due to a decrease in insulin breakdown which was negligeable. It might be attributed to increased insulin binding to muscle insulin receptors; however, this assumption requires caution since insulin receptors were not significantly increased in the livers of the animals (Grizard and Szczygiel, 1983). Furthermore, liver insulin receptors are unchanged in goats or swine with a different dietary protein status (Gill and Hart, 1980; Steele et al., 1981). Alternatively, increased insulin binding to muscle membranes could be attributed to a decrease in $5^{\prime}$-nucleotidase activity. Indeed, our results have been expressed in 5'-nucleotidase activity (see below). When they were expressed in terms of protein in the membrane preparation, the increase in insulin binding in the experimental group did not reach a statistical level of significance (not shown).

$5^{\prime}$-Nucleotidase activity was significantly lower in the experimental group. This decrease could be explained by a decline in $5^{\prime}$-nucleotidase activity after feeding the experimental diet, but this seems unlikely since $5^{\prime}$-nucleotidase is not significantly modified in purified liver plasma membranes of experimental animals (Grizard and Szczygiel, 1983). Furthermore, phosphodiesterase, another enzyme partly occurring in plasma membrane, also decreased significantly $(0.050<p<0.100)$. In fact, $5^{\prime}$-nucleotidase in individual membrane preparations was positively related $(p=0.050)$ to phosphodiesterase. The regression line equation was $y=3.01 x+0.15$, where the enzymatic activity per $\mathrm{mg}$ of membrane protein for $5^{\prime}$-nucleotidase and phosphodiesterase was represented by $y$ and $X$, respectively. Two other events might explain the $5^{\prime}$-nucleotidase decrease observed in the membrane preparation of the experimental group. First, plasma membrane proteins increased as a result of feeding the experimental diet. Such an increase is observed in liver membranes of fasted rats (Almira and Reddy, 1979). Second, plasma membrane protein recovery decreased, whereas that in sarcoplasmic reticulum and mitochondrial components increased. Membrane recovery is unknown since $5^{\prime}$-nucleotidase activity cannot be accurately determined in muscle homogenates (Barrett, Ryan and Headon, 1980). However, the increased $(0.050<\mathrm{p}<0.100)$ yield of cytochrome-c oxidase, a standard mitochondrial marker, suggests a drop in membrane purity. 
Résumé. Les récepteurs de l'insuline dans les membranes des muscles squelettiques d'agneaux ruminants en croissance soumis à différents régimes.

Le but du présent travail est l'étude des récepteurs de l'insuline dans le muscle squelettique chez l'agneau ruminant en croissance $(30-36 \mathrm{~kg}$ ) recevant un régime témoin (lot témoin) ou soumis à une restriction azotée (lot expérimental). Les membranes des muscles sternocephalicus (muscie lent, contenant aussi bien des fibres rouges que des fibres blanches) sont purifiées selon le procédé de Kidwai. Ces membranes, riches en activité enzymatique $5^{\prime}$-nucléotidase, sont composées de la membrane plasmique et des tubes transversaux. L'activité enzymatique cytochrome-c oxydase relativement élevée, traduit leur contamination par des composants mitochondriaux. II est bien établi que de telles membranes contiennent aussi du réticulum sarcoplasmique.

La fixation de $\mathrm{I}^{\prime 125} \mid$ insuline aux membranes purifiées est mesurée à 4 et $30^{\circ} \mathrm{C}$, à différents temps et différentes concentrations en insuline et en membranes. La fixation spécifique de $\left.\right|^{\prime 25} \mid$ insuline augmente avec la durée d'incubation et atteint un maximum au bout de $16-24$ heures (à $4^{\circ} \mathrm{C}$ ) ou $1-2$ heures $(a ̀) 30^{\circ} \mathrm{C}$ ). A $30^{\circ} \mathrm{C}$, elle est proportionnelle à la concentration en membranes. A faible teneur en insuline, la fixation spécifique maximum de $\mathrm{I}^{\prime 25}$ insuline est sensiblement identique aux deux températures. L'élévation de la concentration en insuline provoque une inhibition de la fixation spécifique de $\mathbf{l}^{\prime 125}$ insuline. La fixation spécifique maximum de $\mathrm{I}^{125}$-isuline représente environ $40 \%$ de la fixation totale de $\left.\right|^{125}$-insuline.

La quantité de protéines membranaires récoltée par g de muscle est la même dans les deux lots. L'activité spécifique des enzymes associées au plasmolemme ( 5 '-nucléotidase, phosphodiestérase) est plus fabible dans le lot expérimental que dans le lot témoin; en revanche, l'activité spécifique de la cytochrome-c oxydase est plus élevée. Tout se passe comme si le degré de pureté des membranes est plus faible dans le lot expérimental que dans le lot témoin. C'est pourquoi les résultats sont exprimés par rapport à l'activité enzymatique $5^{\prime}$-nucléotidase. Aux deux températures et pour une gamme très large de concentrations en insuline, y compris celles correspondant à la saturation des récepteurs, la fixation spécifique de $\mathrm{I}^{\prime 22} \mathrm{I}$ insuline est deıx à cinq fois plus élevée dans ie lot expérimental que dans le lot témoin. La dégradation de $\mathrm{I}^{\prime 125}$ insuline au cours des incubations est négligeable dans les deux lots.

\section{References}

ALMIRA E. C., REDDY W. J., 1979. Effect of fasting on insulin binding to hepatocytes and liver plasma membranes from rats. Endocrinology, 104, 205-211.

ARONSON N.N., TOUSTER O., 1974. Isolation of rat liver plasma membrane fragments in isotonic sucrose, 90-102. In FLEISCHER S., PACKER L., Methods in enzymology, vol. 31, part A, Acad. Press, New York, San Francisco, London.

BARRETT E. J., RYAN N. M., HEADON D. R., 1980. The differential release of basal ATP ase, $\mathrm{Ca}^{2+}$-dependent ATP ase, $5^{\prime}$-nucleotidase and cholesterol during homogenization of skeletal muscle. Biochem. J., 188, 569-572.

BASSETT J. M., 1975. Dietary and gastro-intestinal control of hormones regulating carbohydrate metabolism in ruminants, 383-398. In Mc DONALD I. W., WARNER A. C.I., Digestion and metabolism in the ruminant, University New England.

BRADY L. J., GOODMAN M. N., KALISH F. N., RUDERMAN N. B., 1981. Insulin binding and sensitivity in rat skeletal muscle : effect of starvation. Am. J. Physiol., 240, E184-E190.

COOPERSTEIN S. J., LAZAROW A., 1951. A microspectrophotometric method for the determination of cytochrome oxidase. J. biol. Chem., 189, 665-670.

ECKEL J., REINAUER H., 1980. Characteristics of insulin receptors in the heart muscle. Binding of insulin to isolated muscle cells from adult rat heart. Biochim. biophys. Acta, 629, 510521.

ETHERTON T. D., 1982. The role of insulin-receptor interactions in regulation of nutrient utilization by skeletal muscle and adipose tissue : a review. J. anim. Sci., 54, 58-67.

FLAIM K. E., COPENHAVER M. E., JEFFERSON L. S., 1980 . Effects of diabetes on protein synthesis in fast or slow-twitch rat skeletal muscle. Am. I. Physiol., 239, E88-E95. 
FORGUE M. E., FREYCHET P., 1975. Insulin receptors in the heart muscle. Demonstration of specific binding sites and impairment of insulin binding in the plasma membrane of the obese hyperglycemic mouse. Diabetes, 24, 715-723.

FREYCHET P., 1974. The interactions of proinsulin with insulin receptors on the plasma membrane of the liver. J. clin. Invest., 54, 1020-1031.

FREYCHET P., 1976 a. Interactions of polypeptide hormones with cell membrane specific receptors: studies with insulin and glucagon. Diabetologia, 12, 83-100.

FREYCHET P. 1976 b. Insulin receptors, 385-428. In BLECHER M. Methods in receptor research., Dekker M., New-York.

FREYCHET P., KAHN R., ROTH J., NEVILLE D. M., 1972 . Insulin interactions with liver plasma membranes. J. biol. Chem, 247, 3953-3961.

FREYCHET P., ROTH J., NEVILLE D. M., 1971. Monoiodoinsulin : demonstration of its biological activity and binding to fat cells and liver membranes. Biochem. Biophys. Res. Com., 43, 400-408.

GILL R. D., HART I. C., 1980. Properties of insulin and glucagon receptors on sheep hepatocytes : a comparison of hormone binding and plasma hormones and metabolites in lactating and non-lactating ewes. J. Endocr., 84, 237-247.

GILL R. D., HART I. C., 1981. Insulin and glucagon binding to hepatocytes in relation to circulating hormones and metabolites in goats maintained on different diets. Horm. Metab. Res., 13, 603-609.

GOLDBERG A. L., 1979. Influence of insulin and contractile activity on muscle size and protein balance. Diabetes, $28,18-24$.

GOLDFINE I. D., 1978. Insulin receptors and the site of action of insulin. Life Sci., 23, 2639-2648.

GRIZARD J., SZCZYGIEL M., 1983. Insulin binding to liver plasma membranes from growing ruminating sheep maintained on different diets. Horm. Metab. Res, in press.

HOFMANN W. W., NAKANO D. H., 1981. Control of muscle insulin receptors by the motor nerve. Experientia, 37, 286-287.

JEFFERSON L. S., 1980. Role of insulin in the regulation of protein synthesis. Diabetes, 29, 487-496.

KAHN C. R., FREYCHET P., ROTH J., NEVILLE D. M., 1974. Quantitative aspects of the insulin-receptor interaction in liver plasma membranes. J. biol. Chem., 249, 2249-2257.

KAHN C. R., GOLDFINE I. D., NEVILLE D. M., De MEYTS P., 1978. Alterations in insulin binding induced by changes in vivo in the levels of glucocorticoilds and growth hormone. Endocrinology, 103, 1054-1066.

KAPPY M. S., PLOTNICK L. P., MILLEY J. R., ROSENBERG A., MOLTENI R. A., JONES M. D., SIMMONS M. A., 1981. Ontogeny of erythrocyte insulin binding in the sheep. Endocrinology, 109, 611-617.

KIDWAI A. M., RADCLIFFE M. A., DUCHON G., DANIEL E. E., 1971. Isolation of plasma membranes from cardiac muscle. Biochem. Biophys. Res. Commun., 45, 901-910.

LE MARCHAND-BRUSTEL Y., JEANRENAUD B., FREYCHET P., 1978. Insulin binding and effects in isolated soleus muscle of lean and obese mice. Am. J. Physiol., 3, E348-E358.

LOWRY O. H., ROSEBROUGH N. J., FARR A. L., RANDALL R. J., 1951. Protein measurement with the Folin phenol reagent. J. biol. Chem., 193, 265-275.

NEVILLE D. M., 1968. Isolation of an organ specific protein antigen from cell-surface membrane of rat liver. Biochim. biophys. Acta, 154, 540-552.

NEWERLY K., BERSON S. A., 1957. Lack of specificity of insulin-1 ${ }^{131}$ binding by isolated rat diaphragm. Proc. Soc. exp. Biol. Med., 94, 751-775.

OLEFSKY J. M., 1981. Insulin resistance and insulin action. An in vitro and in vivo perspective. Diabetes, 30, 148-162.

OLEFSKY J., BACON V. C., BAUR S., 1976. Insulin receptors of skeletal muscle : specific insulin binding sites and demonstration of decreased numbers of sites in obese rats. Metabolism, 25, 179-191

POSNER B. I., KELLY P. A., SHIU R. P. C., FRIESEN H. G., 1974. Studies of insulin, growth hormone and prolactin binding: tissue distribution, species variation and characterisation. Endocrinology, 95, 521-539.

PREEDY V. R., PAIN V. M., GARLICK, 1980. Sensitivities of rat gastrocnemius and soleus muscles to starvation, insulin and glucagon. Proc. Nutr. Soc., 39, 83A.

SANDRA A., PRZYBYLSKI R. J., 1979. Ontogeny of insulin binding during chick skeletal myogenesis in vitro. Dev. Biol., 68, 546-556.

SAUCIER J., DUBE J. Y., TREMBLAÝ R. R., 1981. Specific insulin binding sites in rat testis : characterization and variation. Endocrinology, 109, 2220-2225.

SCHARRER E., HÜNTEMANN H., BLATT J., 1977. Action of insulin on monosaccharide and amino acid uptake into muscle in lambs. Nutr. Metab., 21, 253-255. 
SINHA M. K., GANGULI S., SPERLING M. A., 1981. Disappearance of erythrocyte insulin receptors during maturation in sheep. Diabetes, 30, 411-415.

SNEDECOR G. W., COCHRAN W. G., 1971. Methodes statistiques. A.C.T.A. ed., Paris.

STEELE N. C., ROSEBROUGH R. W., Mc MURTRY J.-P., FROBISH L. T., 1981. Hepatic insulin receptor characteristics as affected by dietary protein status of swine. I. anim. Sci., 53, suppl. 1, 265-266.

TISCHLER M. E., 1981. Hormonal regulation of protein degradation in skeletal and cardiac muscle. Life Sci, 28, 2569-2576.

TRENKLE A., 1978. Relation of hormonal variations to nutritional studies and metabolism of ruminants. J. Dairy Sci., 61, 281-293.

TURNER M. R., MUNDAY K. A., 1976. Hormonal control of muscle growth, 197-220. In LISTER D., Meat animals : growth an productivity. Plenum Press.

VERNON R. G., CLEGG R. A., FLINT D. J., 1980. Insulin receptors and metabolic activity of sheep adipose tissue during pregnancy and lactation. Biochem. Soc. Trans., 8, 370-371.

VIVEKANANDAN R., SINGH L. N., 1978. Effect of insulin on the incorporation of ${ }^{14} \mathrm{C}$-leucine into subcellular proteins of buffalo skeletal muscles. Indian J.anim. Sci, 48 , 423-427.

WOHLTMANN H. J., NARAHARA H. T., 1966. Binding of insulin- ${ }^{131} \mathrm{I}$ by isolated frog sartorius muscles. J. biol. Chem., 241, 4931-4939. 